\title{
The theory on the construction of system of Chinese procuratorial writ
}

\author{
Zhuo Liu, Yuehong Wu \\ HuNan University Law School, Chang Sha,China \\ Guangdong University of Technology School of Politics and Law , Guang Zhou, China \\ 15203853100@139.com, julia66886@163.com
}

Keywords: Writ,Prosecutorial,China,Neutrality,Weak judicial jurisdiction

\begin{abstract}
China needs to build a system of prosecutorial writ.The system of writ in western developed countries can be used for reference, whether essential, formal or procedural of it. In China, however, because the procuratorial organs have the powers to restrict police, restriction function of procuratorial organs is neutral, procuratorial organs have some weak judicial jurisdiction, combined with the Chinese court exercise such power is not perfect, therefore, to build the system of procuratorial writ becomes reality and necessity.
\end{abstract}

\section{Introduction}

An important aspect of preventing the abuse of police power is to restrict the using of administrative coercive measures and criminal enforcement measures. It is worth noting that the Chinese policemen have a lot of discretion in the use of administrative and criminal coercive measures.In China, not only does administrative reconsideration and administrative litigation exclude these measures, but also the scope of investigation supervision administrative compulsory measures does not include administrative coercive measures, criminal compulsory measures is also lack of specific remedies same rules.In China, there is no obvious difference in the administrative and criminal compulsory measures, sometimes they are even competition.In practice, they are repeatedly replaced by some public security personnels to avoid administrative litigation or increase the time of restriction of personal freedom.For example, in 2002, when a couple see the porn videos, some policemen broke into the home to inspect and helded them in administrative dentention in shanxi in China, the suspect zhang rebelled, when the case was reported, the public security organ to saw the illegal reason was not stand up and turn to lock them up in criminal detention for interference with public function, after the event, their arrest application was not granted, but the suspect is still detained by criminal of 15 , achieved the effect of administrative detention. Another example, in 2005 , the policemmen in the public security bureaue caught four people who robted ancient tombs in the lingbao city. The case should be a criminal case investigation, however, policemen are constrained by their own interests and released them, only fining them. ${ }^{[1]}$

\section{One the overview of system of writ}

Writ system, generally refers to the criminal coercive measures of criminal investigation organs to take, must obtain writ which comes from the agency of judicial referee, and exercise according to these writ, in order to prevent the police power for the violation of civil liberties. It begans in Britain from the 12th to 13th century. At first, the writ was issued by the king mainly, because of the application of one, its purpose was to settle the case of justice, and then gradually to be issued by the magistrate, anyone could apply. This system effectively guarantees the rights of citizens, in the meanwhile, also limits the police power due to procedural examination.

\section{International experience of system of the writ and its enlightenment to China}

At present, the system of judicial writ is widely established in western countries.In comparison with these countries, the common characteristics of these countries are:in terms of its substantial requirements, requirements of criminal compulsory measures must have a certain reason in two legal systems, and the reason should be fairly objectivity, such as common law emphasizes the "possible causes", but also stresses the reason should has certain objective evidence requirements, while the law in Germany requirements "strong doubts" in arrest phase, of course, this kind of strongly suspect is not arbitrary,has certain evidences, which are judgment criteria; In terms of the 
form, two legal systems both put specificity as its content of writ,which should have, namely writ were due to a specific place and the execution of the reasons, the scope and for the specific people or things, etc.; On the issuing body, although compared to the mainland legal system, Anglo-American legal system more emphasis on that writ should be issued by the men who are neutral and detached, but two big legal systems put the judge as the main body who normally issue writs, even in Germany, just give the prosecutor the authority of issuing temporary writs in the case of an emergency; In terms of its relief procedures, the two legal systems have set it twice, one either before or after the issuance of a trial, the other before a trial or a trial.

The establishment of system of writ is of great positive significance. In terms of its value, not only does inhibit indictment of the police and safeguard human rights, but also maintenances legitimacy, authority and legitimacy of the enforcement measures of,as well as protecting the legal rights of officials. ${ }^{2]}$ Therefore, in order to limit the using of coerceive measures of police and guarantee the rights of Chinese citizens, China should actively draw lessons from the international writ system and draw on its own strengths.

\section{4.the establishment of systems of China's procuratorial writ}

In order to control the power of the police, it is necessary for China to construct a system of judicial writ system, which conforms to China's national conditions. Hereinafter referred to.

First of all, the procuratorial organ has the legal restraint power to the policeman. The Chinese constitution gives procuratorial organs the constitutional authority to restrain public power by positioning the procuratorial organ as the legal supervision organ; the organization law and the criminal procedure law of the people's procuratorate of China once again give the procuratorial organs the power to restrain the investigation activities, the judicial activities and the enforcement activities in the criminal proceedings; The law of the people's police also generalizes the principle that the police should perform their duties under the supervision of procuratorial work; The law of administration of public security also gives citizens the regulation about informing and indicting the violation of discipline and law of policemen. Cover these regulations not only the restrictions on criminal behavior of policemen, but also contain restrictions on their administrative actions. Of course, for the procuratorial supervision in the people's police law, this article interprets it as a constraint, rather than as a mere supervision of post facto behavior.

Secondly, the restraining function of procuratorial organ is neutral. Neutrality is the cornerstone of your system of writ. To the neutrality of procuratorial organs, the European court of human rights accords regulation that a judge or other officials who attains legal authority review arresting from policeman or behavior of arresting, in the form of decision, puts forward the neutrality of the prosecutor does not depend on its properties, but depends on independent of the party and administrative. According to this view, if the restriction function is played properly,the Chinese procuratorial organ can have a strong independence: Firstly, the constitution and the organization law of the procuratorates give the procuratorial organs the independence to exercise their powers and to avoid of interference which is the principle of procuratorial independence in the process. Secondly, in the system of design of reality, the procuratorial organ has no common tasks for the common administrative violations handled by the police, which is similar to that of criminal prosecution.

Thirdly, the procuratorial organ has some weak judicial jurisdiction. The essence of judicial jurisdiction is the power of judgment and decision, does which exist not only in the judicial organs, but also in the administrative organs and procuratorial organs.For example, in the United States, the administrative judge is a member of the administrative organs and the French administrative court is established in the administrative system, which is based on the theory of judicial non-interference.In China, the procuratorial organ always has the power of adjudication, the power of public prosecution and other weak judicial jurisdictions.Moreover, the exercise of this power by China's procuratorial organs has not been questioned for a long time.Therefore, we can also infer that it is feasible for Chinese procuratorial organs, rather than judicial organs, to decide to exercise using of compulsory measures from public security organs.

Finally, the Chinese courts exercise this power is not perfect.One is the conflict with the enforcement of the power to arrest by the procuratorial organ.If the court exercises the decision of compulsory measures, and procuratorial organs exercise their power to arrest in criminal cases, and the power of judicial review of criminal cases is separated to exercise by two institutions, so, mutual exclusion is prone to power, which affects the working efficiency of the public security organ;The second is the violation of the principle of due process of law. The principle of due process of law comes from France in 13th century, the principle requires the court's ruling on any disputes should 
follow the requirements of the "natural justice", means any person or organization shall not become a self judges, referee of litigation should listen to both sides. If the court exercises this power, as a judge at the trial,the court had to to make up their own review to the validity of using of compulsory measures, this is a clear conflict with the principle of due process of law. ${ }^{[3]}$

Of course, at the moment of establishment of deciding power of that procuratorial organs exercise compulsory measures ,not only does we should consider fully attribute of the rights of client, location, situation is urgent and the will of parties, when we put the using decision of legal business qualification to the procuratorial organ , which also involves more severe compulsory measures,personal freedom and dignity, involves large amount of fines, but also should focus on not to reduce the request of the efficiency of police procedurals, endow them with a small amount of self-determination and the power to use for the first step in a hurry.

\section{Summary}

Doubt and criticism are the bridges of academic progress. Li siguang once said: "no doubt,nobody can not discover the truth".With the establishment of China's national supervision committee, the overall transfer of the anti-corruption department of our procuratorate has been launched. Under such background, it is necessary and urgent to discuss the perfection of procuratorial system. We only has accurately grasped the essence of western writ system, unswervingly followed the objective law and actively learned from construction experience of western writ system, combined with China's specific national conditions, to further promote the reform of criminal investigation system in our country.

Western writ system not only inhibits the police indictment and safeguard human rights,maintenances the legitimacy of the enforcement measures, the legitimacy of authority ,but also protect the legal rights of officials at the same time ${ }^{[4]}$ Therefore, in order to restrict the using of police force and protect further the rights of Chinese citizens, it is a good idea to use the international system of writ to establish experience. In China,however, because the procuratorial organs have the powers to restrict police, restriction function of procuratorial organs is neutral, procuratorial organs have some weak judicial jurisdiction, combined with the Chinese court exercise such power is not perfect, therefore, to build the system of procuratorial writ becomes reality and necessity. The establishment of system of writ of Chinese style is not the work in one day, also not be accomplished by the procuratorial organs alone, realize the close cooperation between the public prosecutor and the security organ and search the special road to realize needs to have further research for authors.

\section{Acknowledgements}

The project of the 13th five-year plan of the development of philosophy and social science in guangzhou city "the research on the comprehensive governance by law in GuangZhou city in the era of Big Data " (No.2018GZQN28 ), the constructive project of the 13th five-year plan of the philosophy and social sciences in Guangdong province "the research on the comprehensive governance by law in Guangdong provence in the era of Big Data " (No. GD17XFX13), The Chinese postdoctoral program which is supported by the scientific fund " the system of procedural control of admiting punishment and leniency "(No. 2016M602437)

\section{References}

[1]. TaoQu, the discrimination between the administrative coercive measures and criminal compulsory measures of public security organs,CONTEMPORARY LAW REVIEW, vol.5,pp.56,2003

[2]. ChangjiuSun,FengGao,the analysis of the judicial writ system in criminal investigation.THE SOCIETY IN GUANGDONG PROVINCE,vol.2,pp.144-148,2006; YuanshengSong,the theory on the effect of the balance of the writ of justice -- based on the comparative perspective of the British and American writ system,vol.1,JOURNAL OF GANSU POLITICAL SCIENCE,vol.pp.144-148,2011

[3]. XuewenHuang,JinwenCun,the discussion on judicial control of police administrative 
act. Science of Law - Journal of Northwest University of Political Science and Law | Sci Law,vol.2,pp.153-156,2011.

[4]. ChangjiuSun,FengGao,the analysis of the judicial writ system in criminal investigation.THE SOCIETY IN GUANGDONG PROVINCE,vol.2,pp.144-148,2006; YuanshengSong,the theory on the effect of the balance of the writ of justice -- based on the comparative perspective of the British and American writ system,vol.1,JOURNAL OF GANSU POLITICAL SCIENCE,vol.1,pp.134-139,2011. 